\title{
Oil and Wildlife in Alaska
}

\author{
By Peter Scott
}

The discovery in Alaska of oilfields that promise to be among the richest in the world has raised some complex problems for conservationists. Alaska has a rich and impressive wildlife and habitats that are extremely vulnerable; in summer, when the surface soil thaws out on top of the permanently frozen layers below, one caterpillar tractor can make scars that may lead to disastrous erosion and take years to heal. And how are migrating caribou to get over the unburied parts of a four-foot diameter pipeline that runs for hundreds of miles across their traditional routes. BP, conscious of their responsibility for the wildlife and the habitat, asked Peter Scott to go to Alaska and report on the situation and what could be done to minimise the impact of the oil developments on the wildlife. The following account is drawn in part from his report and in part from his article published in the house magazine BP Shield.

People need oil, and now it must flow out of the Arctic. How can it be made to flow with the minimum of damage to the country it comes from-the hitherto unspoiled country- 'the barren grounds' of the far north ? Almost four-fifths of the area enclosed by the Arctic Circle is sea (ice-covered for most of the year). The land in the Arctic is not much used by people (compared with land areas in other latitudes), but it is extensively used by great numbers of other kinds of animals-many, though not all, migrating into it in summer with the melting of the snow and the break-up of the ice; for them the Arctic is their summer home and breeding ground.

Alaska-the name I was told means the Great Land-is rich in large mammals and birds, and in fish; they include whales, walrus, seals, bears (four kinds), wolves, wolverines, sea otter, river otter, lynx, musk ox, bison, caribou, moose, mountain goats, Dall sheep, cranes, swans (two kinds), geese (seven kinds), ducks (seventeen kinds), eagles (two kinds), osprey, falcons (four kinds), buzzards (four kinds), ptarmigan (three kinds), many species of sea birds and waders, and even humming birds. There are five kinds of salmon. Of the mammals and birds ten are under some threat of world extinction: these are the fin, blue, humpback, bowhead (or Greenland right) and North Pacific right whales, glacier bear, polar bear, Aleutian Canada goose, trumpeter swan and Eskimo curlew. A further four are endangered in Alaska although more numerous elsewhere: gray whale, grizzly bear, ribbon seal and American peregrine falcon. In addition, the habitat in Alaska-the natural environment-is extremely vulnerable. Wounds take long to heal and may not heal at all. This is particularly true of tundra-the so-called barren grounds-under most of which the ground remains permanently frozen.

It was to assess this situation that the chairman of BP, Eric Drake, 


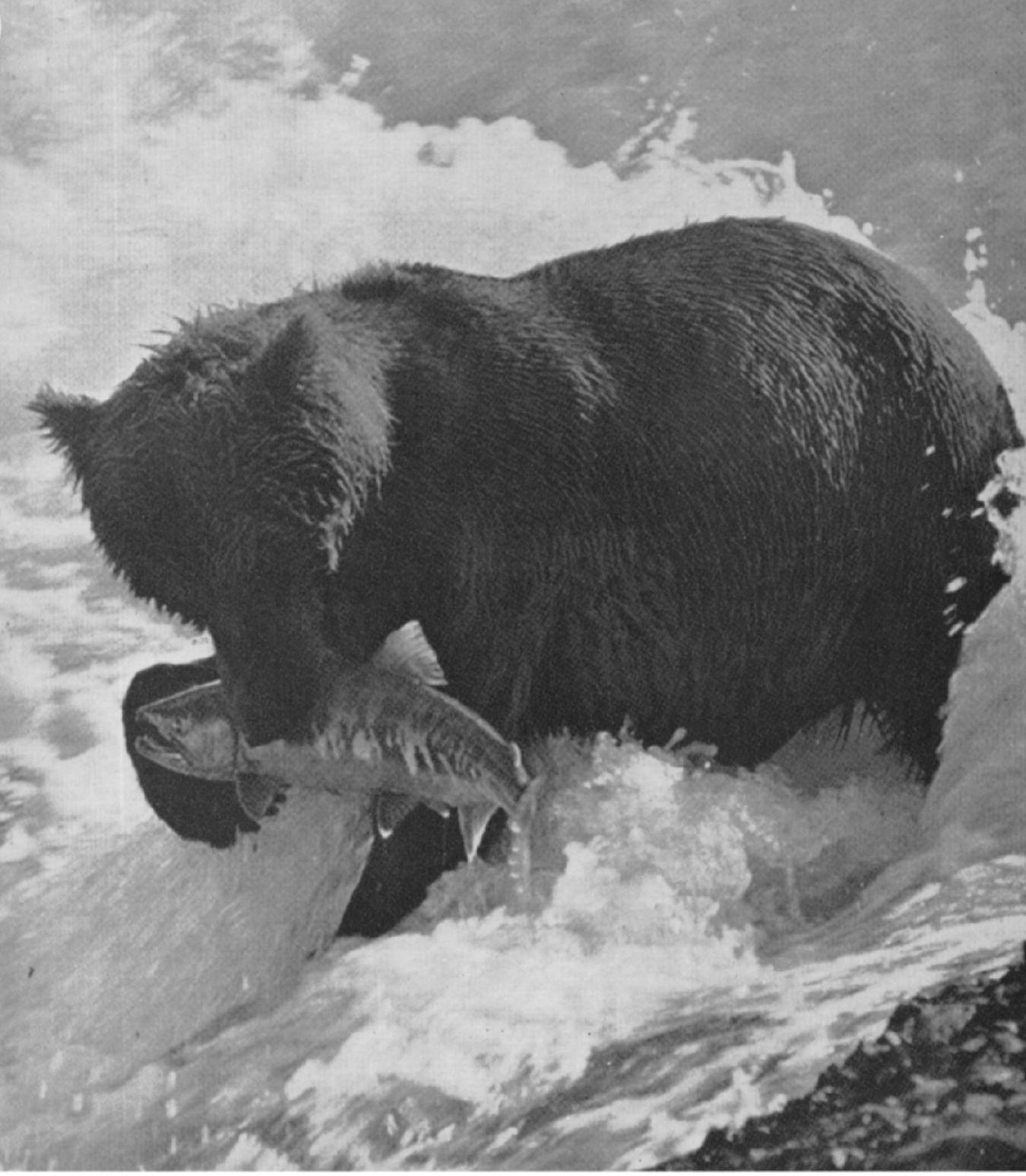

Plate 1

SALMON FISHERMAN-an Alaskan grizzly bear gets a fish that was on its way up river to spawn. Eugen Schuhmacher, reproduced from The Last of the Wild by permission 

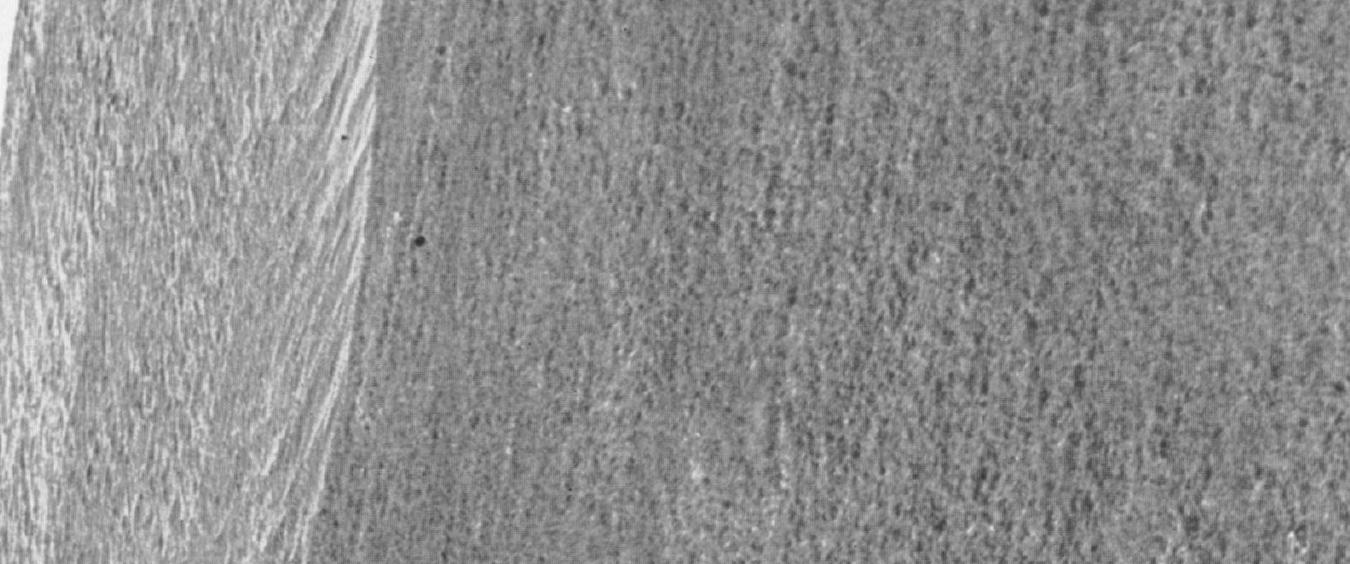

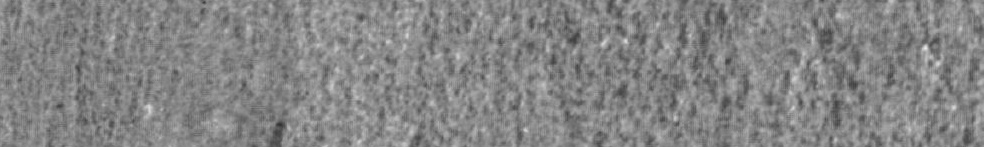

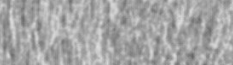

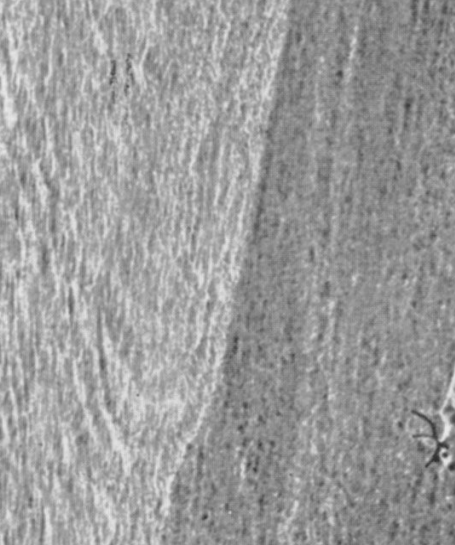

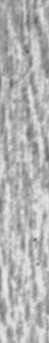

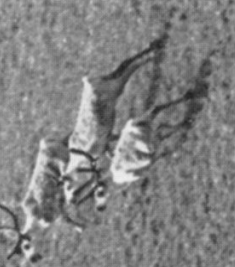

bytis:

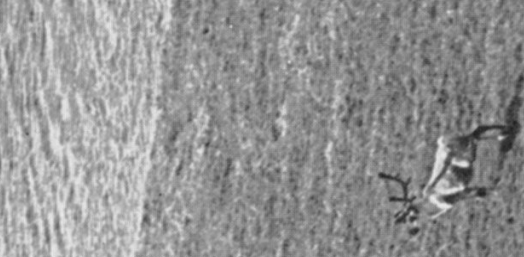

if

\section{1., $12 \times 10^{2}$}

$$
\text { 1. }
$$

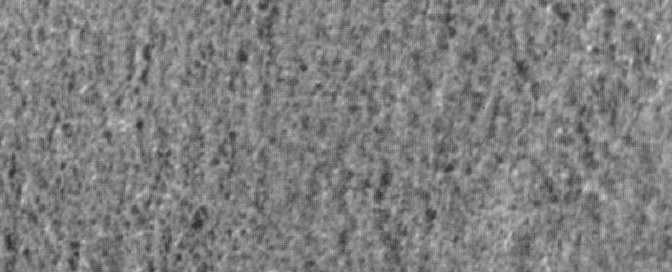

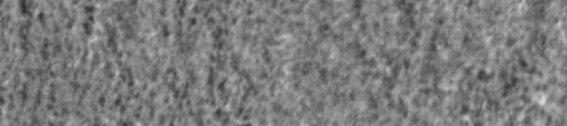

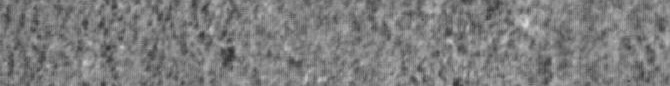
7.

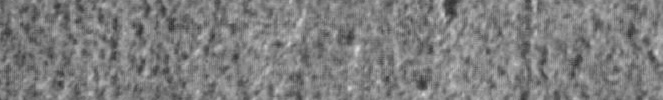
23. (2) 130.

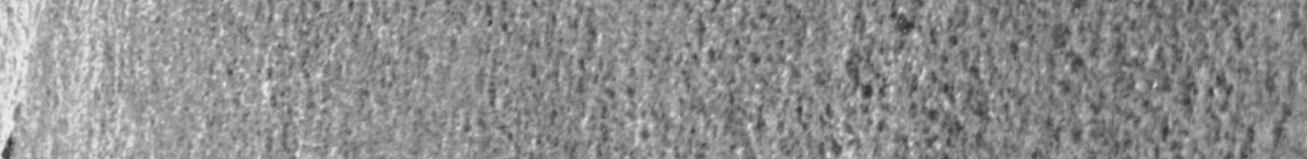

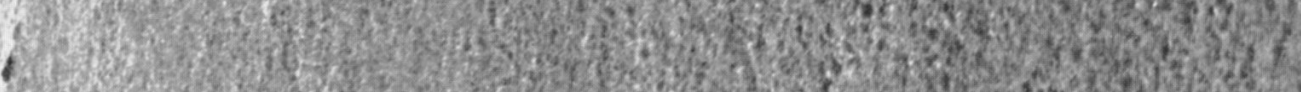

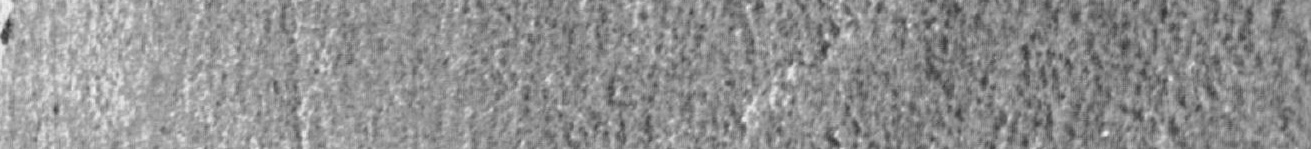

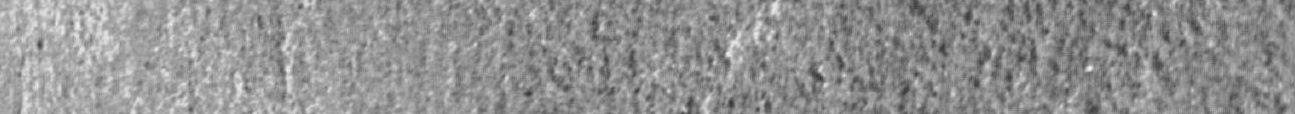

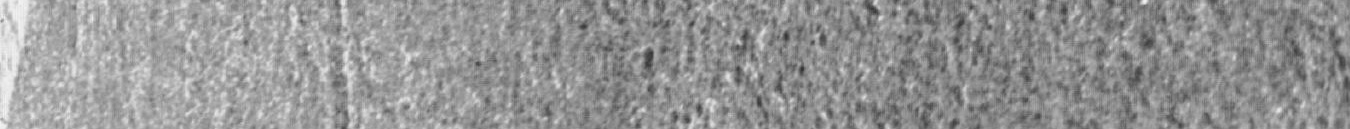

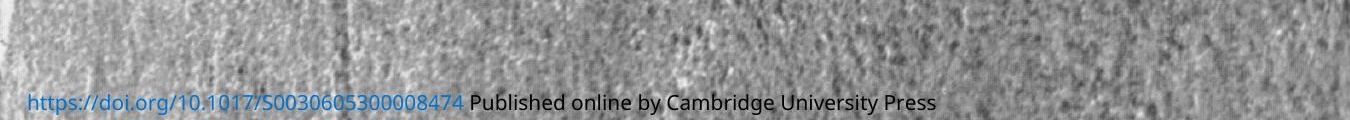



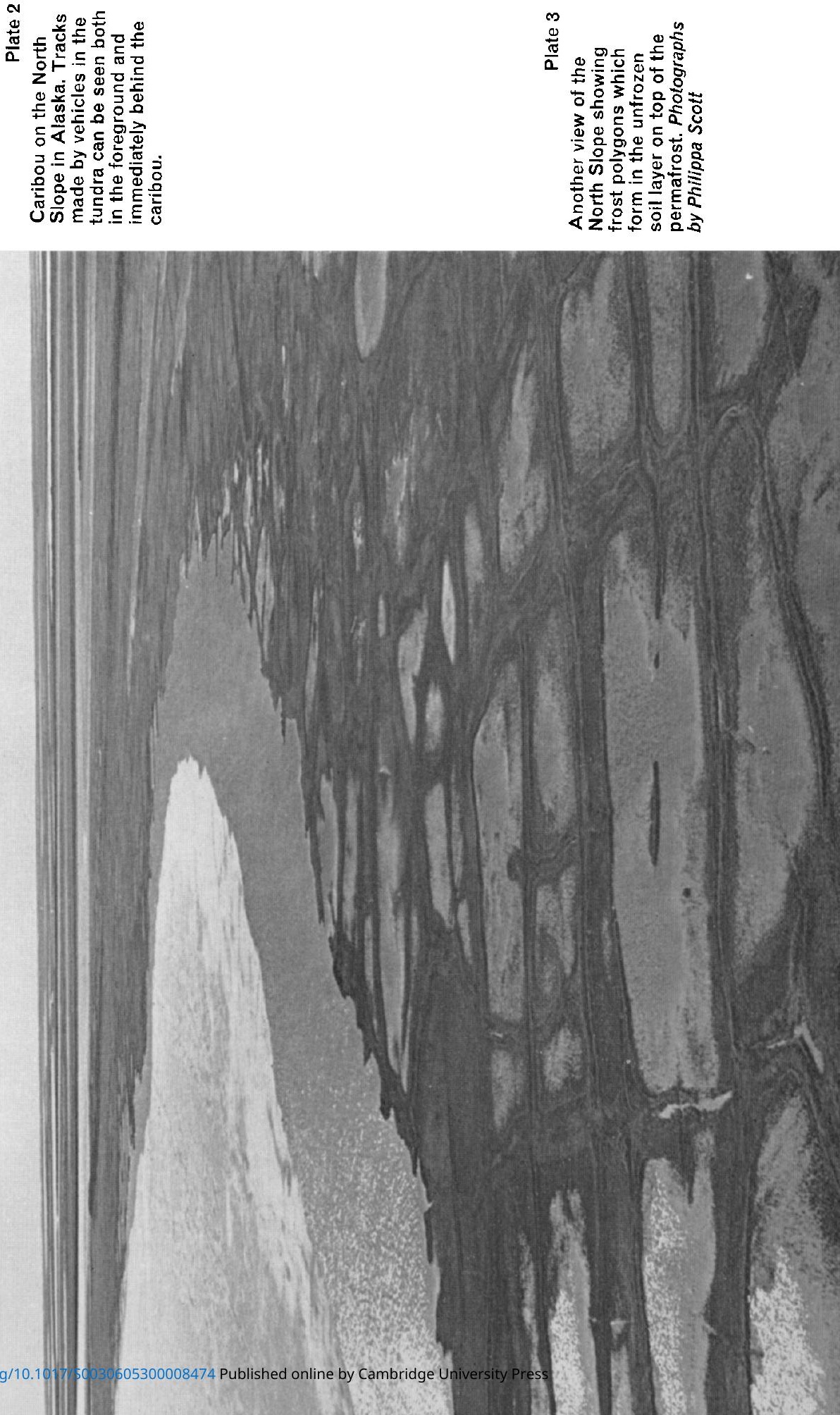


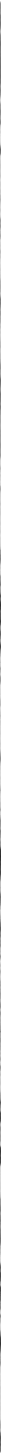

Plate 4

Aerial view of the Brooks Range and Fulton River on the route of the proposed trans-Alaska pipeline. British Petroleum 
invited me to go to Alaska and report on the probable impact on Alaska's wildlife of the oil development on the North Slope, the trans-Alaska pipeline and the projected tanker operations in the Beaufort Sea and the Pacific Ocean.

And thus, in bright sunshine one afternoon in June 1969, my wife (who came as photographer) and I found ourselves alighting from a helicopter on the North Slope-the vast expanse of the coastal plain which does not appear to slope in the smallest degree. The spot had been chosen because it had scarcely yet been disturbed by development at all, and we were anxious to see the unspoiled wildlife of the tundra in this area. We stepped down into a cold north-east wind blowing directly off the sea ice, and the brown grass, not long free of snow, was studded with early Arctic flowers.

Immediately we found ourselves among a wealth of birds. A breeding colony of Pacific black brant geese had at least twenty nests. A dozen white-fronted geese flew past and we heard the liquid call so familiar at Slimbridge in winter. There were pintails and long-tailed ducks (which the Americans call old squaw); black-throated divers (which they call Arctic loons), both Arctic and long-tailed skuas (they call them jaegers) and pectoral sandpipers displaying. A bar-tailed godwit may have had a mate sitting nearby; a grey plover (black-bellied) flew past, dunlins and semipalmated sandpipers were everywhere, and so were the two species of phalaropes. We found the nests of both-the rednecked (northern) and the grey (which is bright orange red in summer, hence known to Americans as the red phalarope). The beauty and tameness of these elegant little birds, which swim as easily as ducks, is to my mind one of the most delightful things about the Arctic. The last time we had seen grey phalaropes in numbers had been in February 1968 out at sea off the coast of Chile, conceivably even the very same birds, for during the northern winter these tiny waders make a vast migration from the Arctic almost to the Antarctic, living at sea on surface plankton and sitting on the water often in large 'rafts'. There were Arctic terns, glaucous and Sabine's gulls, and as we walked back to the helicopter we flushed a cock rock ptarmigan, which landed about thirty yards away beside a superb cock Lapland bunting, with his black head and bright chestnut nape. Between them was a magnificent head of the deep pink Arctic lousewort Pedicularis lanata and a clump of snow buttercups Ranunculus nivalis. The old ptarmigan's eye-brow combs shone scarlet in the sun as he sat proudly, almost aggressively watching us. It was one of those unforgettable glimpses of a rare perfection. Later landings brought us close to whistling swans, king eiders, red-throated divers and the powerful pomarine skua with its curiously twisted tail feathers; from the air we saw snow geese and snowy owls, and a great many caribou.

To see the wildlife of the 'unspoiled' tundra was important, but how unspoiled is 'unspoiled'? Already, even in the apparently limitless expanse of 'the barrens', we could scarcely see, from the air, a square mile that was not crossed by the caterpillar tracks of the seismic crews, or of some other vehicle with business in the Arctic. Many of the tracks 
Oryx

PIPELINES

Completed

- _ Builbing or Proposed.

ALASKA

\section{BEAUFORT SEA}

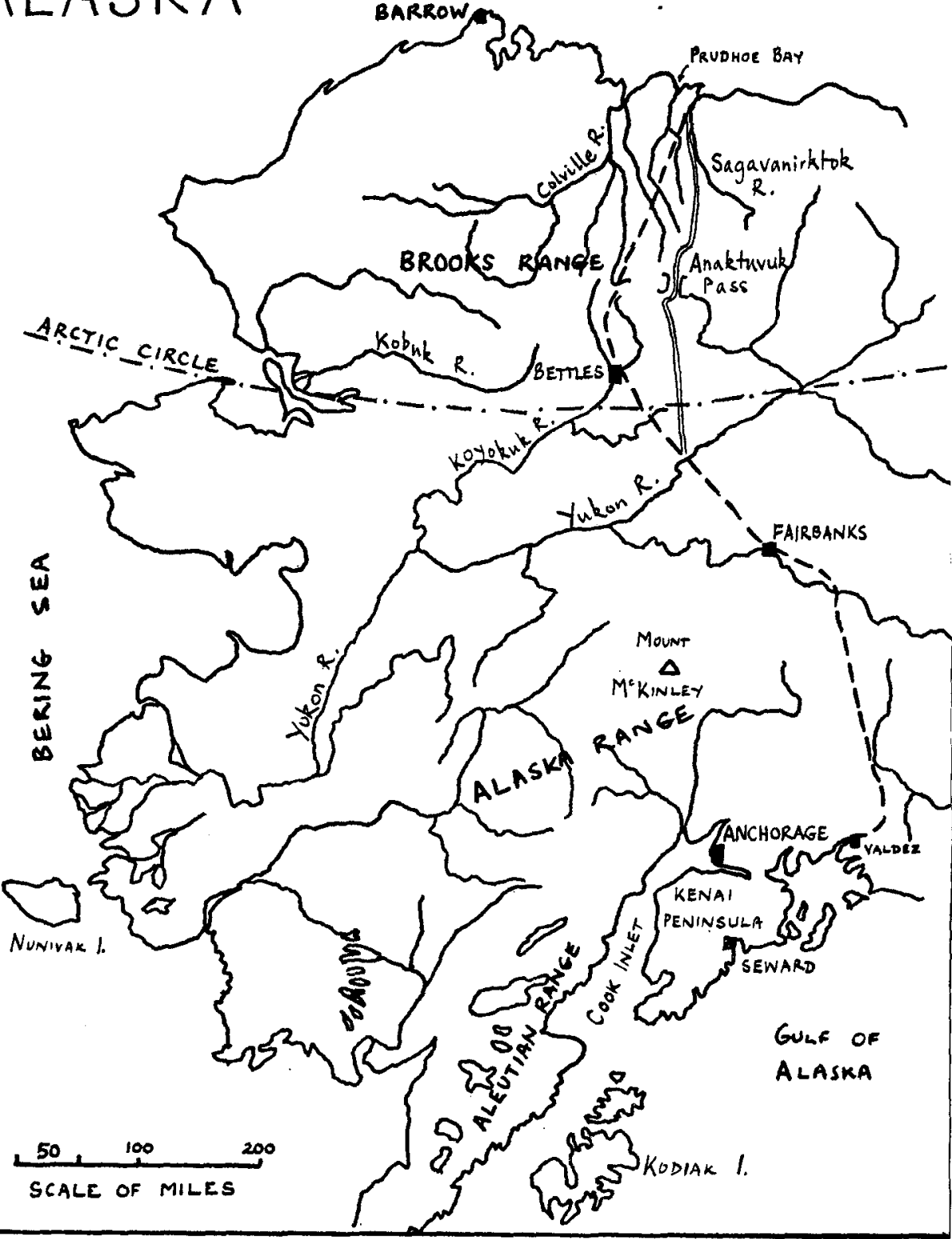


were apparently years rather than months old, for the tundra heals slowly. Many had started new erosion that will be detectable still a hundred years hence, perhaps a thousand. We were shown the track made by a single vehicle taking a short cut back to camp one evening which, in three months, had created a creek ten feet deep and thirty feet wide over a length of about 300 yards. It is hard to imagine that such small causes can have such striking effects. The reasons are two interacting characteristics of the tundra - 'permafrost' and 'the run-off'. Even in midsummer the surface layer of unfrozen peaty soil is no more than a foot or two thick above earth which is permanently frozen. In the spring, when the snow melts and the ice breaks up, a lot of surface water is produced all at once, and if its run-off is deflected along new channels it will quickly cut deep into the permafrost.

This is only one of the ways in which man alters the terrain on the North Slope. There is also the disposal of rubbish including vast numbers of drums; there is the disposal of sewage; there is the risk of oil leaks and spills, and chemical pollution; there is the direct disturbance caused by the constant passage of low-flying air traffic which may lead to large scale egg predation by gulls and skuas; there is the new disturbance factor which may be involved when the hovercraft comes in. But probably the biggest differences will come from the very fact that there will be many more people in places which formerly had many less. Even when the construction period is over numbers are likely to be greatly in excess of former times when, on the North Slope for example, only a few hunting Eskimos and occasional trappers or prospectors ever went there.

On the sea, too, the effects of a regular summer service of giant tankers through the Northwest Passage are likely to be considerable. Apart from the possibility that the ice might catch and hold such ships immobile through a whole winter, or might cause damage to the tanks, the risks are of the usual type with bulk carriers-leakage through collision and grounding. Then, too, we do not yet know how well the bacteria will be able to break down oil under the north polar sea ice. With less oxygen available and less wave motion, the oil might last a great deal longer (though it is claimed it would also be easier to contain with booms-if they happened to be available). Then there is the tanker terminal to consider-currently suggested for Herschel Island off the Canadian coast. No tanker terminal has so far managed to operate without any spillage at all-although it is claimed that methods of confining and collecting spills are nowadays incorporated in the plans.

The trans-Alaska pipeline, which will cut 800 miles across the 49th State from Prudhoe Bay south to Valdez at a cost of about $\$ 900,000,000$, also poses problems of leakage, and other potential dangers to wildlife and the environment. Unless a significant part of it can be buried it is likely to interfere with the migration of the vast herds of caribou which at present cross the proposed route twice a year in their tens of thousands. Burying the 48-inch pipe-ultimately probably two 48 -inch pipes-in permafrost terrain is difficult and expensive enough, but it will also involve immense problems of potential erosion. The oil is likely to come 
out of the ground at quite a high temperature-some say as high as $180^{\circ} \mathrm{F}$; and because of friction in the pipe it will not apparently have cooled so very much by the time it reaches Valdez 800 miles to the south. The pipeline must cross a number of rivers on its way-including the mighty Yukon; it must also cross a vast number of small tributary streams, and Alaska is famous for the salmon-five different kinds of them-which run up these rivers to spawn in the tributaries. Will the pipeline increase river erosion, cause turbidity, damage the gravel beds where the fish spawn, cause pollution or even alter the water temperature so as to prevent the salmon from entering the stream at all ? Before the pipeline can be built a gravel road must be laid along the route. How much will this road affect the wilderness and its wildlife? The oil companies say that all but 60 miles of the pipeline will be buried and that the uncovered parts will be in lengths ranging from a few yards to Io miles. They are confident that there will be no serious erosion problems nor damage to river gravels where fish spawn. We must hope that their confidence is well grounded. Certainly they are conducting exhaustive experiments, in conjunction with the University of Alaska, on pipelines buried in various types of terrain.

\section{Dall Sheep and Caribou Paths}

To get some idea of the pipeline project we went by helicopter from Sagwon, the camp 70 miles from the coast where we had stayed overnight, up the Sagavanirktok River and the Atigun River to the Dietrich Pass. This route is being surveyed by a small team under the management of Chuck Ristau. There was also just a chance of seeing barren ground grizzly, one of the world's rare animals, Dall sheep-the pure white wild sheep which live on the high tops, and moose. In the event the grizzlies failed us, but we found the Dall sheep on the face of a steep canyon and landed briefly to watch them climbing their criss-cross paths up the near-vertical opposite face of the canyon. On the moorland slope where we stood the alpine flowers were marvellous-and quite different from those of the tundra - and the mosquitoes were terrible. Later we found a bull moose, with his antlers still in velvet, who stood undisturbed as the helicopter passed close to him. The Antigun River valley is steep in its upper waters and the altimeter read just over 5,000 feet as we slipped over the Dietrich Pass where the pipeline will probably go through the Brooks Range. The pass is only 200 yards wide and we could clearly see the paths of the caribou which walk over it in spring and autumn in their thousands.

It was sad to think of the road and the pipe and the rubbish of untidy man that must come into this wonderful wild place. But the oil must flow, and if the reserves on the North Slope are as great as is currently believed, it may be flowing out at the rate of five million barrels a day by 1980 , when the field is in full production, with a gross profit of $\$ 4 \frac{1}{2} \mathrm{~m}$. a day. At that rate is should be possible to take all reasonable steps to minimise the damage. It should be possible to time the building of road and pipes so as not to interfere with the caribou migration and the salmon spawning. It should be possible to stick to a code of conduct, 
to control the construction and service operators, to limit the wanderings of the vehicles, and the lowness of the aircraft, to dispose of rubbish and sewage acceptably and to keep on learning how to do it better by detailed long-term study of the effects as the work progresses. This pipeline will be the first in the Arctic-a precedent which demands that it be done well. For that reason the Ecological Survey Team under Bryan Sage, put into the field by BP, is doing a highly important job along the proposed route. But it must be a long-term study, which will record how it all works out when the pipe and road are in use.

\section{Over Exploitation}

Alaska has a long history of over-exploitation of its resources-three species of whale brought to the verge of extinction, and massive depletion of the Pacific walrus. At one time the Pribilov fur seal was in trouble; now it is the polar bear. Mineral exploitation has had a chequered history too-gold, now oil, maybe in the future copper. It always seems to be a 'rush', with too little time to think of the long-term implications and the side-effects. Exploitation of the renewable resources has so far rarely been planned on a sustained yield basis. Indeed, only in the case of the fur seals, on their remote breeding island in the Behring Sea, has there been a recovery from the initial over-kill to the current management plan for rational use of a large, healthy and relatively stable population.

Many of the birds breeding in Alaska migrate southwards in autumn through Canada to that part of the US which the Alaskans call 'the lower 48', and even into Mexico in winter. The ducks and geese are a substantial part of the quarry of duck hunters and of bird watchers while on passage and in their winter quarters. Wildlife therefore constitutes an international renewable resource which must be properly husbanded and nurtured. Already tourism based on hunting and fishing and photography brings a significant return. In the future it can bring vastly more, with a long term swing away from killing for fun. Alaska has some of the finest scenery in the world-including the highest mountain in North America (Mount McKinley 20,320 ft.) It has a climate which is continental in the centre and oceanic at the edges. On one of the days of our visit the temperature in Fairbanks was in the high eighties whereas over the North Slope it was a bare $40^{\circ}$. Alaska has forests, snow mountains, tundra, sea cliffs, fjords, marshes, rivers and a million lakes. Man has already laid his mark on the Great Land, and that mark is seldom beautiful.

But a time may yet come when economic return is no longer the only standard by which to value the beauty and diversity of nature. Then maybe the last remaining wildernesses in the world will be valued as wildernesses and be rated more highly than the minerals which happen to lie underneath. Meanwhile let us see that more care than ever is taken to avoid further damage to Alaska. Much can be learned from past mistakes. There is much to be learned from the oil field in the Kenai Peninsula south of Anchorage, where, after no more than twelve years of development, the wells and installations are now remarkably well 
integrated into the countryside. We landed close by one installation in a Grumman Goose flying-boat to take a closer look at a brood of the world's largest and rarest swans-trumpeters. There were many pairs on these forest-fringed lakes, and moose were grazing in the shallow water.

So it can be done. It may be more difficult on the North Slope, but I think most people will agree that if it can be done, it must be done. I think there is a good chance that it will be done, but the pressure in favour of conservation must never be relaxed. It must be exerted unceasingly, vigorously and with dogged determination, over a long period by those who mind about the Arctic tundra and its rich variety of wildlife.

\section{Recommendations}

The main recommendations of my report to the Chairman of BP included:-

I. The oil company should make liaison with agencies concerned with Arctic ecology and wildlife and the Oil Liaison Committee set up by the US Secretary of the Interior.

2. A Code of Conduct should be drawn up for all company and contractors' employees.

3. Urgent attention should be given to waste disposal and tidiness.

4. All vehicles should be restricted, especially in permafrost areas, to 5 -foot thick gravel roads to avoid further erosion.

5. Hovercraft should be confined to specific tracks, and aircraft restricted to a minimum ceiling of 1000 feet, to minimise disturbance, especially to breeding birds.

6. Road-building by bulldozing the material from the sides to the centre should be stopped.

7. Special care should be taken, in consultation with wildlife agencies, in the timing of construction work so as to minimise interference with natural cycles of plants and animals, e.g. migration, breeding.

8. Nature reserve status should be considered for all lands leased by the company and the ban on firearms should be maintained.

9. A fully qualified ecologist should be employed by the company.

10. Encouragement should be given to employees to take an interest in wildlife, and a wildlife film should be made.

II. Present ecological survey of the pipeline route should be expanded in scope and extended in time, and the oil company should support the IBP (International Biological Programme) tundra research studies.

I2. Consideration should be given to setting up an Arctic Information Centre for Alaska, in consultation with the relevant scientific bodies; and facilities and a small laboratory should be provided for research at Prudhoe Bay.

\section{Fish Kills}

In the USA $15,236,000$ fish died as a result of water pollution in 1968 , an increase of $3 \mathrm{I}$ per cent on 1967 , according to the annual report of the Department of the Interior. 